DOI https://doi.org/10.30525/978-9934-26-114-5-47

\title{
НОВІТНІ ТЕНДЕНЦІЇ У ВИКЛАДАННІ МОВ: ВИЩА ШКОЛА
}

\author{
Дьячкова Я. О. \\ кандидат педагогічних наук, \\ доцент кафедри іноземних мов економічного факультету \\ Київський національний університет імені Тараса Шевченка \\ Сизенко А. C. \\ кандидат філологічних наук, доцент, \\ доиент кафедри іноземних мов економічного факультету \\ Київський національний університет імені Тараса Шевченка \\ м. Київ, Україна
}

Виклики сьогодення, пов'язані 3 пандемією, дистанційним навчанням, відкритим доступом до освітніх ресурсів (переважна більшість 3 яких - англомовні) тощо, надали синхронній та асинхронній комунікації стратегічної цінності на рівні з іншими освітніми ресурсами. Це спонукало сучасну вищу освіти до якісного розвитку, вдосконалення та налагодження процесів навчання та викладання. Беззаперечно, нова соціокультурна реальність зробила вивчення іноземних мов (IM) одним із пріоритетних завдань для майбутніх фахівців та зумовила, тим самим, необхідність модернізації сучасної системи вищої іншомовної освіти. Також в умовах гуманізації та стрімкого розвитку полікультурного суспільства відбувається переосмислення культурно-ціннісних орієнтирів у вищій освіті України, що значно актуалізує потребу в підготовці фахівців, здатних до кроскультурної комунікації засобами іноземної мови в інноваційно-технологічному просторі. Це зумовлює пошук нових освітніх парадигм і концепцій, принципів та підходів до організації освітнього процесу, а також методів, форм і засобів навчання студентів, упровадження технологічних інновацій, які сприятимуть підвищенню якості іншомовної освіти. Організація навчання майбутніх фахівців із застосуванням технологічних інновацій сприятиме формуванню базових компетентностей, готовності до застосування технологічних інновацій у майбутній професійній діяльності, розвитку універсальних соціальних навичок («soft skills») європейського рівня. Зазначимо також, що важлива роль у процесі створення і використання технологічних інновацій належить системі вищої освіти як основному джерелу висококваліфікованих кадрів і потужній базі фундаментальних і прикладних наукових 
досліджень. А специфіка вищої школи полягає в тому, що вона є, 3 одного боку, споживачем, а 3 іншого - активним виробником цих самих інновацій.

В цій роботі розглядаються основні сучасні цифрові освітні інструменти в контексті викладання IМ у закладах вищої освіти (ЗВО). Оскільки процес викладання та засвоєння IM вважається складнішим від аналогічних процесів для більшості інших предметів, підвищення ефективності та результативності навчання $\epsilon$ актуальною темою для дослідження та вбачається нами у діджиталізації освітнього процесу, що сприяє широкому використанню інноваційних методів навчання мови.

До важливих факторів, що визначають сутність використання сучасних інноваційних освітніх методів і технологій, належать:

- інтенсифікація навчання, що повинна сприяти ефективності професійної підготовки особистості;

- система новітніх засобів навчання, структура та зміст навчального матеріалу, організаційна структура, методи й засоби навчання, фактори педагогічного середовища;

- комплексний підхід до інтенсифікації процесу навчання, пов'язаний з проблемою оптимізації цього процесу як цілісної системи за допомогою сучасних інформаційно-комп'ютерних систем.

Однак, механізм практичної реалізації освітніх інновацій у ЗВО розроблено недостатньо, що актуалізує більш детальне практичне вивчення сучасних тенденцій у викладанні IM.

Зазначимо, що сучасні інноваційні методи навчання IM спрямовані на розвиток і самовдосконалення особистості, на розкриття іiі резервних можливостей та творчого потенціалу, створюють передумови для ефективного поліпшення освітнього процесу у вищих закладах освіти. Беручи до уваги також сучасні умови навчання, освітній процес спрямований на формування і розвиток основних навичок та вмінь у соціальному та професійному спілкуванні, а також стратегій самостійного вивчення іноземних мов $[1$, с. 4$]$.

Таким чином, діджиталізація викладання IM є якісною характеристикою індивідуалізації професійної підготови фахівців, що є процесом перетворення всіх процесів навчання та вивчення IM на основний потік цифрової реалізації освітніх процесів: посібники 3 електронного навчання, е-навчальні посібники, е-методи та інструменти для вивчення IM, DVD-матеріали, аудіоматеріали, електронні словники та створення університетської мережі в майбутньому [3].

Процес викладання IM у системі університетської підготовки фахівців сьогодні можна та потрібно урізноманітнити за допомогою 186 
використання новітніх інформаційно-комп’ютерних технологій. Викладач повинен вміти послуговуватися такими основними інструментами як презентація інформації з наочною підтримкою у системах PowerPoint, Prezi, Keynote, Google Slides, Tilda, Canva, Office Sway, Piktochart, Paste, Mentimeter тощо.

Корисним $\epsilon$ також впровадження на заняттях 3 IM роботи 3 інтерактивними ресурсами, що можуть бути інтегровані у платформи Zoom, Microsoft Teams, або платформах розроблених ЗВО для внутрішнього користування (наприклад, платформа дистанційної освіти 'KNU EducationOnline', розроблена в рамках проекту КНУ ім. Т. Шевченка «Цифровий університет. Університет у смартфоні», яка призначена для проведення занять, створення інтерактивного графіку навчального процесу в Університеті, для розміщення викладачами матеріалів до освітніх курсів, розробки інтерактивних навчальних завдань для студентів та для забезпечення реалізації іншого інструментарію дистанційного навчання). Тут маються на увазі освітні сервіси та платформи для створення та проведення вікторин, тестів та мовних ігор: Kahoot, Plickers, Quizlet, Poll Everywhere, Learningapps тощо.

Іноземні видавництва сьогодні створюють мобільні додатки до більшості нових підручників з ІМ. Ці ресурси підходять для активізації самостійної роботи студентів, коли, працюючи в індивідуальному режимі у зручний час та зручному місці, студенти можуть виконати комплекс інтерактивних вправ і таким чином поглибити та покращити свої знання мови не лише під час аудиторної роботи, але і самостійно [2].

Корисним засобом навчання на заняттях з ІМ виступають діаграми або картки зв'язків (англ. Mind Map, нім. Wortwolke). Вони активізують процес побудови студентами монологічних повідомлень іноземною мовою, дозволяють наочно встановити взаємозв'язок «слово-реченнятекст».

Існує також чимало Інтернет-інструментів для побудови тестових завдань різного типу, з цією метою можна ефективно використовувати тестові компоненти платформи Moodle, Майстер-Тест, Online Test Ped, Classroom, Kahoot, Quizizz тощо.

Зазначені вище засоби діджиталізації освіти та цифрові освітні інструменти для кожного викладача ЗВО слід зробити своїм методичним та професійним надбанням. Це дозволить надати процесу викладання в українській вищій школі загальносвітового виміру, i зробить у майбутньому за умови постійного та ефективного використання цього цифрового інструментарію вітчизняну освіту конкурентоспроможною на ринку світових освітніх послуг. 


\title{
Література:
}

1. Іщенко О. Вивчення англійської мови в умовах вступу України у європейський освітній простір / О. Іщенко, О. Матвіяс. // Вісник Львівського університету. 2009. №25. С. 353-357

2. Попадюк С. С, Скуратівська М. О. Здійснення іншомовної підготовки студентів закладів вищої освіти засобами віртуального освітнього середовища. Іншомовна підготовка працівників правоохоронних органів $i$ сектору безпеки: матеріали III Міжнародної науково-практичної конференції (м. Київ, 27 бер. 2019 р.). Київ, Національна академія прокуратури України, 2019. С. 158-160

3. Chernionkov Ya. The Digitalization of the Educational Process as a Qualitative Characteristic of the Individualization of a Future Teacher of Foreign Languages' Professional Training // Astraea, Vol. 1, № 1, 2020. Retrivered from: file:///C:/Users/yanad/Downloads/3033-6070-1-SM.pdf

DOI https://doi.org/10.30525/978-9934-26-114-5-48

\section{USING THE DISCUSSION IN TEACHING A FOREIGN LANGUAGE AT THE ESTABLISHMENTS OF HIGHER EDUCATION OF THE MINISTRY OF INTERNAL AFFAIRS OF UKRAINE}

\author{
Zelenska O. P. \\ Doctor of Pedagogy, Full Professor, \\ Professor of the Department of Foreign Languages and Culture \\ of Professional Speech \\ Lviv State University of Internal Affairs \\ Lviv, Ukraine
}

The method of active training that gives the student or cadet the possibility to join the language environment of active speech complies with the new requirements of the social, professional and international communication. At present the professional communication demands the communicative and cognitive approaches that provide the correlation between the language structures and the speech activity. The methods of teaching a foreign language as a means of the communication is based on acknowledging the fact that realizing the language in the speech activity the speaker does not only express something but also manifests the notion and carries out the fully defined communicative function [1, c. 120]. A student as a personality and searching for those means that will help to intensify their 